\title{
Enhancement of Low Calorie Chocolate Milk Sweetened with Stevioside and Texturizing Inulin \\ Jehan I. Saber ${ }^{1}$, Hayam H. Mohamed ${ }^{1}$; Zeinab Ismail ${ }^{2}$; and Mona I. Massoud ${ }^{3}$
}

\begin{abstract}
Physico-chemical , microbiological characteristics and sensory evaluation were performed to investigate the effect of replacing sugar with stevioside as well as the addition of texturizing inulin as a functional ingredient on the quality of the low calorie chocolate milk. Low caloric chocolate milk has been prepared by replacing $25,50,75$ and $100 \%$ of sugar with stevioside and addition of inulin (frutafit ${ }^{\circledR}$ TEX) to improve texture parameters. The results indicated that the total soluble solids of all chocolate milk decreased as the ratio of the stevioside added increased compared to the control samples. No significant differences were found between the organoleptic properties for all samples sweetened with stevioside compared to the control. The addition of $2 \%$ inulin increased the chocolate milk viscosity. Chocolate milk samples replacing $50 \%$ sugar with stevioside and $2 \%$ inulin had gained the highest overall acceptability scores compared to those prepared using sugar alone and qualities of similar textures of full-fat products. These low products can be used for people suffering from obese and diabetics.
\end{abstract}

Keywords: Stevioside, inulin, organoleptic properties, diabetics

\section{INTRODUCTION}

Dairy products can supply consumers with all nutrition benefits of milk in a desired state and largely tast consumed by different ages. However, most of the consumers are now health conscious and prefer to use products that are high in its nutrition, reduced calorie and therapeutic values. Therefore, there is an increasing interest especially important as customers look in utilization of sugar substitute in food products to production of good quality low calorie foods and reducing thus health risks associated with excessive sugar intake such as diabetes, obesity and heart related diseases. Stevioside, a high-intensity natural sweetener is about 200 to 300 times sweeter than sucrose and is characterized by a fast-acting impact sweetness and synergistic properties with other sweeteners (Abdelnabey and Massoud, 2013 and Marcinek and Krejpcio, 2016). It is non-caloric and heat stable, and offer therapeutic benefits (Singh et al., 2015; Marcinek and Krejpcio, 2016). The JECFA (Joint Food and
Agriculture Organization/World Health Organization Expert Committee on Food Additives ) permitted for use as a sweetener in 2005 .

Inulin is a natural texture modifier that used in the food to enhance the technological characteristics (Tungland and Meyer, 2002). Long chain oligosaccharides and concentration of inulin affect rheological behavior in products. It shows a creaminess, thickness and texture close to those of the fat food items and has "bifidogenic effect" as a prebiotic ingredient and gives a caloric value $1.5 \mathrm{kcal} / \mathrm{g}$ (Silva, 1996 , Villegas and Costell, 2007 and Niness 1999). The production of functional foods reduced in sugar and fat with at the same time meet nutritional requirements is most important of meeting consumer demand that provide health benefits.

The present study is aimed to investigated the effect of stevioside as a sugar substitute on the organoleptic attributes and some physico-chemical properties of low milk characteristics. Also, inulin is used as a functional ingredient with stevioside to prepare low calorie prebiotic chocolate milk to suitable for diabetic and a carbohydrate controlled diet.

\section{MATERIALS AND METHODS}

Skimmed milk and whole cow's milk were obtained from Extension Factory for Dairy Production - Faculty of Agriculture - Alexandria University. Inulin (Frutafit@ TEX, chain length $\geq 23$ monomers ,Sensus, Brenntag Qumica, Spain),sugar, cocoa powder, and gelatin were obtained from the markets in Alexandria, Egypt.

\section{Sample preparation:}

The first stage for preparing chocolate skimmed milk was made to select the best replacement of sucrose to prepare low-calorie processed milk with stevioside. The amount of stevioside was calculated according to relative sweetness of sucrose. These trials were as follows: Control (100\% sucrose), replacing $25 \%, 50 \%$, $75 \%$ and $100 \%$ of sucrose by stevioside. The formula of chocolate skimmed milk manufacture was prepared as described by $\mathrm{Rad}$ et al. (2012) was as the follows: $7.5 \%$ sugar, $0.75 \%$ cocoa, and $0.1 \%$ gelatin. The heated

\footnotetext{
${ }^{1}$ Department of Home Economics - Faculty of Agriculture Shatby University of Alex. Egypt.

${ }^{2}$ Department of Dairy Science and Technology - Faculty of Agriculture Shatby - University of Alex. Egypt.

${ }^{3}$ Crops Research Institute, Agriculture Research Center, El-Sabahia, Alex. Egypt.

Received April 12, 2018, Accepted May 30, 2018
} 
skimmed milk was added to the ingredients in a dry pan and the temperature was raised to $90{ }^{\circ} \mathrm{C}$ for 3 min for pasteurization. The samples were stored under $4{ }^{\circ} \mathrm{C}$ until sensory analysis.

The second stage was to optimize the formula in the previous stage which was accepted by the panelist for the chocolate milk which was selected to be applied to prepare the low caloric prebiotic chocolate milk with inulin at ratio 0,1 and $2 \%$.The samples were stored at $4 \pm 1^{\circ} \mathrm{C}$ for 14 days. Each sample was taken for physicchemical,and microbiological analysis.

Physico-chemical analyses: Milk was analyzed for moisture content, crude fat, crude protein, ash and titratable acidity according to the methods of the AOAC (2000). Total carbohydrate was calculated by difference. The $\mathrm{pH}$ value was measured using a $\mathrm{pH}$ meter. Total soluble solids (TSS) of milk samples were determined using a Hand refractmeter (MVx100 Beckman, USA) at $20{ }^{\circ} \mathrm{C}$ for zero, 7 , and 14 days of storage. The viscosity all the milk samples were measured using NDJ-8S Viscosimeter (Digital, China) at $20^{\circ} \mathrm{C}$, The samples were analysed in three replicates.

Microbiological analysis: Total viable count (TVC) analysis were carried out following Difco (2009).

Sensory evaluation: Sensory evaluation for milk samples were done according to Salem and Mowafy (2001) as follow: flavour 15 points, body \& texture 35 points, taste property 30 points and colour 20 points . Samples were served to the panelists and they were asked to rate the acceptability of the product.

Statistical analysis: The data were analysed using SPSS statistical analysis software package (Version 21).

\section{RERSULTS AND DISCUSSION}

\section{Chemical composition:}

The comparison between chemical for whole milk and skimmed milk are given in Table (1). It was clear that whole milk contained high level of total soluble solids $(18.57 \%)$ and fat $(3.6 \%)$ compared to skimmed milk(15.75 and $0.4 \%$ respectively ). On the other hand the mean content of protein was equally in whole milk as well as in skimmed milk (3.1\%) and total carbohydrates were $11.65 \%$ in skimmed milk, which are not significantly different from whole milk $(\mathrm{p}>0.05)$. As shown from Table (2), total energy in whole milk $(91.35 \mathrm{kcal} / 100 \mathrm{~g})$ was higher than total energy in skimmed milk $(62.87 \mathrm{kcal} / 100 \mathrm{~g})$. These findings are in agreement with the data reported by Abou-shloue (1999) and Mittal and Bajwa(2012).

Table1. Chemical composition of chocolate milk made from Skimmed and whole milk

\begin{tabular}{lcc}
\hline \multicolumn{1}{c}{ Component $* \%$} & $\begin{array}{c}\text { Skimmed } \\
\text { Milk }\end{array}$ & Whole milk \\
\hline Moisture content & $84.25 \pm 0.01$ & $81.43 \pm 0.01$ \\
Total soluble solids & 15.75 & 18.57 \\
Crude fat & $0.4 \pm 0.01$ & $3.6 \pm 0.01$ \\
Crude protein & $3.1 \pm 0.01$ & $3.1 \pm 0.01$ \\
Ash & $0.60 \pm 0.01$ & $0.62 \pm 0.01$ \\
Total carbohydrates $* *$ & $11.65 \pm 0.01$ & $11.25 \pm 0.01$ \\
Total energy (kcal/100g) & $62.87 \pm 0.01$ & $91.35 \pm 0.01$ \\
\hline${ }^{*}$ On wet weight basis **Total carbohydrate was calculated by difference
\end{tabular}

ffect of stevioside on physico-chemical, microbiological properties of low calorie chocolate milk drink

The data in Table (2) illustrate the changes that occurred in $\mathrm{pH}$, acidity, TSS ,total viable count, and total energy characteristics of low calorie chocolate milk samples which were prepared using stevioside at different levels. It can be noted that the T.S.S. of all chocolate milk samples decreased as the ratio of the stevioside added increased in comparison to the control milk drinks. These results are in agreement with those of Salem et al. (2003) and Mittal and Bajwa (2012) who reported that The increase levels of sugar replacement caused a reduction of TSS in producing low fat ice cream. On the other hand $\mathrm{pH}$ values were not affected by the change in the formula of milk samples compared with the control samples. These results are in agreement with Cedex ( 2001) who mentioned that the alkalinity of cocoa milk produced ranged from 7-9. These results are in agreement with the data reported by Moussa et al., (2003) and Salem and Massoud (2003).

Microbial content of fresh or stored chocolate milk showed that total viable count were not detected in $0.1 \mathrm{gm}$ of samples. This is due to the good hygienic conditions during manufacture and storage. Abdoun et al (1996) obtained similar results for ice cream.

Table2. Physico-chemical properties of low calorie chocolate milk

\begin{tabular}{lcccccc}
\hline Parameter & Whole milk & Skim milk & Replacing sugar with stevioside & \\
\cline { 5 - 7 } & $(\mathbf{1 0 0 \%}$ ) sugar) & $(\mathbf{1 0 0 \%}$ sugar) & $25 \%$ & $50 \%$ & $75 \%$ & $100 \%$ \\
\hline TSS( \%) & 18.57 & 15.75 & 13 & 12 & 10 & 9 \\
PH & 6.99 & 7.03 & 7.05 & 7.05 & 7.05 & 7.04 \\
Acidity (\%) & 0.14 & 0.14 & 0.13 & 0.13 & 0.13 & 0.13 \\
TVC(cfu/ml) & 4 & 4 & 4 & 4 & 4 & 4 \\
Calories & 91.35 & 62.87 & 59.16 & 47.6 & 40.12 & 32.6 \\
\hline
\end{tabular}


Effect of sucrose replacement with stevioside on the sensory properties of chocolate skim milk

The average scores for sensory evaluation of chocolate skimmed milk prepared by sucrose replaced by stevioside sweetener are presented in Tables (3). The data in Table (3) revealed that all milks prepared and sweetened with stevioside had the higher score of taste (sweetness) compared with the control samples. On the other hand, no significant differences were recorded in colour, texture, flavor and overall acceptability chocolate skimmed milk sweetened with stevioside compared with the control samples. The milk chocolate prepared from replacing sugar with steviosideat $50 \%$ had the higher score of sensory profile compared with others milk chocolate samples sweetened with different concentration of stevioside. These results are in accordance with the data reported by Devereux et al., (2003), Massoud et al., (2005) and Kattab et al., (2017). Panelists accepted all the chocolate skimmed milk prepared from up to $75 \%$ replacing sugar by stevioside

Effect of texturized inulin on the viscosity,physicchemical and microbiological characteristics of chocolate skim milk
Viscosity value of the studied samples are summarized in Figure (1).it can be noted that samples containing sucrose had the highest viscosity value and it was obvious that viscosity decreased with increasing sugar replacement level. Also, these results are in agreement with Alizadeh et al. (2014a,b) who reported that the viscosity of ice- cream mixes decreased by adding of stevia. It is also clear from Figure (1) that viscosity of low caloric milk drinks, increased with increasing the percentage of inulin. It raised from $6.3 \mathrm{cP}$ in skimmed milk sweetened with $50 \%$ stevioside to 8 and $9 \mathrm{cP}$ of low fat chocolate skim milk containing $1 \%$ and $2 \%$ inulin, respectively. This can be attributed to inulin which acts as a stabilizer due to its high capacity to bind water (Blomsma,1997). Also Salem et al., (2003) reported that the artichoke inulin and oat improved the viscosity of low sugar ice cream. The interaction of inulin with milk protein can lead to an increase in the molar mass which results in an increase in viscosity (Gonz?lez-Tom?s et al., 2008). The addition of $6 \%$ and $8 \%$ inulin to skimmed milk products perceived reduced viscous and creamy as compared with the whole-milk sample (Gonz?lez- Tom?s et al., 2009).

Table 3. Effect of sucrose replacement with stevioside on the sensory properties of chocolate skimmed milk drink

\begin{tabular}{lccccc}
\hline Parameter & \multicolumn{4}{c}{ Skimmed milk } \\
\cline { 2 - 6 } & $\mathbf{0}$ & $\mathbf{2 5 \%}$ & $\mathbf{5 0 \%}$ & $\mathbf{7 5 \%}$ & $\mathbf{1 0 0 \%}$ \\
\hline Appearance/Colour & $18.50 \pm 1.45^{\mathbf{a}}$ & $18.08 \pm 1.44^{\mathbf{a}}$ & $18.67 \pm 1.07^{\mathbf{a}}$ & $18.58 \pm 1.08^{\mathbf{a}}$ & $18.58 \pm 1.08^{\mathbf{a}}$ \\
Flavour & $14.83 \pm 0.39^{\mathbf{a}}$ & $14.17 \pm 1.53^{\mathbf{a}}$ & $14.92 \pm 0.29^{\mathbf{a}}$ & $14.83 \pm 0.58^{\mathbf{a}}$ & $14.75 \pm 0.87^{\mathbf{a}}$ \\
Taste & $27.00 \pm 2.00^{\mathbf{a}}$ & $28.00 \pm 1.81^{\mathbf{b}}$ & $28.42 \pm 1.56^{\mathbf{b}}$ & $27.83 \pm 1.53^{\mathbf{b}}$ & $27.27 \pm 1.37^{\mathbf{b}}$ \\
Texture & $33.92 \pm 1.16^{\mathbf{a}}$ & $33.92 \pm 1.62^{\mathbf{a}}$ & $34.08 \pm 1.16^{\mathbf{a}}$ & $33.83 \pm 1.27^{\mathbf{a}}$ & $33.70 \pm 1.27^{\mathbf{a}}$ \\
Overall & $94.25 \pm 4.00^{\mathbf{a}}$ & $94.83 \pm 4.30^{\mathbf{a}}$ & $96.08 \pm 3.53^{\mathbf{a}}$ & $95.08 \pm 3.06^{\mathbf{a}}$ & $94.30 \pm 2.98^{\mathbf{a}}$ \\
acceptability & & & &
\end{tabular}

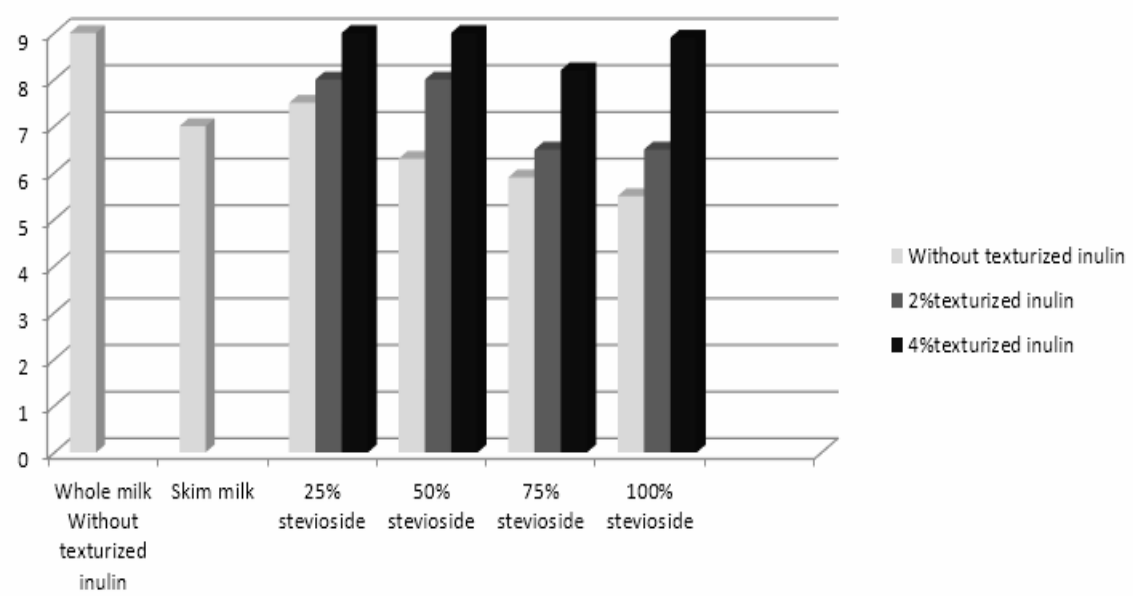

Figure 1. Effect of inulin on viscosity of chocolate skim milk sweetened with steviosideas sugar replacement 
Table 4. Physicochemical and microbiological and sensory properties of low colorie chocolate Skimmed milk containing texturizing inulin

\begin{tabular}{lcccccc}
\hline Property & Full Milk & \multicolumn{6}{c}{ Replacing } & \multicolumn{5}{c}{ sugar with stevioside and adding 2 \% inulin Skimmed milk } \\
\cline { 2 - 7 } & 0 & 0 & $25 \%$ & 50 & 75 & 100 \\
\hline Total soluble solids (\%) & 18.57 & 15.75 & 15 & 14 & 12 & 11 \\
pH & 6.99 & 7.03 & 7.05 & 7.04 & 7.06 & 7.05 \\
Acidity (\%) & 0.14 & 0.14 & 0.13 & 0.13 & 0.11 & 0.14 \\
TVC (cfu/ml) & 4 & 4 & 4 & 4 & 4 & 4 \\
Sensory Properties & & & & & & \\
\hline Colour(20) & $18.50 \pm 1.47^{\mathrm{a}}$ & $18.50 \pm 1.45^{\mathrm{a}}$ & $18.58 \pm 1.44^{\mathrm{a}}$ & $18.58 \pm 1.44^{\mathrm{a}}$ & $18.58 \pm 1.44^{\mathrm{a}}$ & $18.15 \pm 0.97^{\mathrm{a}}$ \\
(Flavour)15 & $14.83 \pm 0.39^{\mathrm{a}}$ & $14.13 \pm 0.39^{\text {ab }}$ & $14.73 \pm 0.39^{\mathrm{a}}$ & $14.85 \pm 0.62^{\mathrm{a}}$ & $14.50 \pm 1.00^{\text {ab }}$ & $14.37 \pm 0.89^{\mathrm{b}}$ \\
Taste(30) & $26.33 \pm 2.57^{\mathrm{a}}$ & $27.00 \pm 2.00^{\mathrm{a}}$ & $28.42 \pm 1.31^{\mathrm{b}}$ & $28.77 \pm 0.65^{\mathrm{b}}$ & $28.55 \pm 0.62^{\mathrm{b}}$ & $26.00 \pm 1.41^{\mathrm{a}}$ \\
Texture(35) & $33.58 \pm 1.56^{\mathrm{a}}$ & $31.92 \pm 1.16^{\mathrm{b}}$ & $33.42 \pm 1.38^{\mathrm{a}}$ & $33.33 \pm 1.83^{\mathrm{a}}$ & $33.32 \pm 1.38^{\mathrm{a}}$ & $31.33 \pm 1.27^{\mathrm{b}}$ \\
Overall & $93.00 \pm 3.74^{\mathrm{a}}$ & $90.25 \pm 4.00^{\mathrm{b}}$ & $95.25 \pm 3.20^{\mathrm{a}}$ & $95.33 \pm 3.08^{\mathrm{a}}$ & $95.25 \pm 3.19^{\mathrm{a}}$ & $89.25 \pm 3.17^{\mathrm{b}}$
\end{tabular}

acceptability $(100)$

Addition of $2 \%$ inulin can be used to produce low calories products which had similar texture characteristic properties and no considerable changes were noticed in viscosity values in whole milk as compared to skimmed milk samples .Tarrega and Costell (2006) reported that fat -free dairy desserts using whole milk or inulin skimmed milk showed higher consistency and shear thinning than skimmed milk. Abd El-Razeketal (2013) reported that inulin can be utilized as texturizing agent and as a natural food ingredient to fat in the production of low-calorie food.

The data in Table (4) illustrate the changes that occurred in $\mathrm{pH}$, acidity ,TSS and microbiological characteristics of low calorie milk samples which were prepared with $2 \%$ texturized inulin as a texturizing agent. The total soluble solids content of skimmed milk decreased with the increase stevioside and increased by adding inulin .These may be due to the solubility of inulin in water which it caused an increment in the total soluble solids.

A slight increase in $\mathrm{pH}$ values and slight decrease in titratable acidity were noticed in the low milk drink sweetened with stevioside than the control samples. Modzelewska-Kapituła and Kłębukowska (2009) reported that inulin did not affect the $\mathrm{pH}$ values and the yoghurt bacteria counts.

In the sensory evaluation, the data presented in Table (4) show the organoleptic attributes of chocolate milk sweetened stevioside containing inulin . Addition of $2 \%$ inulin caused a significant increase in taste and overall acceptability of chocolate and had a better acceptability than the inulin free products. The addition of $2 \%$ inulin enhanced the taste and overall acceptability attributes of chocolate skimmed milk in comparison with the chocolate whole milk. On the other hand, no differences can be observed for texture attribute value where the same scores were given by the panelists for different samples containing $2 \%$ inulin. It was obvious that products containing $50 \%$ stevioside showed the highest overall acceptability in all the sensory attributes in comparison to the control ones. Also, no significant differences could be traced concerning the scores given by the panelists for the flavor and colour. Modzelewska-Kapituła and Kłębukowska (2009) concluded that adding inulin in yoghurt as fat replacer, could provide a means of reducing fat intake with acceptable sensory characteristics. The low calorie milk product made with $100 \%$ sucralose could possibly be improved by the addition of some bulk improvers ( Mittal and Bajwa 2012). These results confirmed the work of $\operatorname{Rad}$ et al (2012) .The addition of a small amount of inulin imparts a creamier mouth feel in low fat dairy products (Frank, 2002). Long-chain inulin addition to low fat yoghurt, chocolate mousse and custards resulted in enhanced creaminess (Gonz?lez-Tom?s et al. , 2009a,b).

Nutritive value of the milk drinks. The calorific value of the formulation containing stevioside was reduced as compared to the control samples, it can be concluded that $50 \%$ stevioside and $2 \%$ inulin could be replace a sucrose in of chocolate milk for producing a product with the same sensorial properties of chocolate milk and to reduce caloric value with about $50 \%(47.6 \pm 1 \mathrm{kcal} / \mathrm{g})$ (Table,2).

\section{Effect of storage at refrigerator on chemical analysis} and microbial content of chocolate milk:

The $\mathrm{pH}$ and the total soluble solids in all chocolate skimmed milk did not changed after two weeks of storage at $20^{\circ} \mathrm{C}$ samples compared with chocolate produced by whole milk. After 14 day of storage, the viscosity values of samples decreased. There was no considerable difference in the TVC content of all treatments $(>10 \mathrm{cfu} / \mathrm{ml})$ during storage period. 


\section{REFERENCES}

A.O.A.C .2000. Official methods of analyses, 16th edn. Association of Official Analytical Chemists, Washington DC.

Abd El-Razek , Amal, M. , T. M. Alnemr, and M. I.Massoud.2013. Potential Utilization of Texturized Inulin as a Fat Replacer in Some Food Products ,Alex. J.of Food Sci. \& Technol,10: 13-22 .

Abdel-nabeyA.A.and M. I.Massoud.2013.Stevia Sweeteners: An Overview. Alexandria J.of Food Sci. \& Technol.10: 112

Abdoun, Sania A., E.A. Montasser and H.A. Younis .1996. Evaluation of some blends for dietetic and diabetic ice cream. Egyptian J. Dairy Sci. 24:103-114

Abou-shloue, Z.I. 1999. Preparation and evaluation of low calories long shelf-life chocolate flavoured milk. J .Agric Mansoura Univ. 24: 4129-4138.

Alizadeh M, M.A Lalabadi and S. Kheirouvris. 2014a Impact of using steviaon physicochemical sensory rheology and glycemic index of softice cream. Food NutrSci :390-396

Alizadeh M, M. A. Lalabadi and S. Kheirouvris .2014b.Effect of Stevia as a substitute for sugar on physicochemical and sensory properties offruit based milk shake. J Sci Res Rep 3:1421-1429

Blomsma, C.A.1997. Ingenious. Inulin. International Food Ingerdients.2:22.Codex stan105-1981,Rev.1-(2001).

Devereux, H. M., G.P.Jones, L.Mecormack, and W.C. Hunter. 2003. Consumer acceptability of low fat foods containing inulin and oligofructose. J. Food Sci. 68:1850-1854.

Difco and BBL Manual .2009.Manual of Microbiological Culture Media Second Edition.

Frank, A. 2002. Technological functionality of inulin and oligofructose. British J. of Nutr. 87: 5287-5291.

Gonz?lez-Tom?s L., J.Coll-Marqués, and E.Costell. 2008. Viscoelasticity of inulin starch-based dairy systems. Influence of inulin average chain length. Food Hydrocolloids. 22: 1372-1380

Gonz?lez-Tom?s, L., S.Bayarri, and E.Costell.2009b. Inulinenriched dairy desserts:physicochemical and sensory aspects. Journal of Dairy Science, 92: 4188-4199.

Gonz?lez-Tom?s, L., S.Bayarri, J.Coll-Marqués, and E. Costell.2009a. Flow behaviorof inulin-enriched dairy desserts. Influence of inulin average chain length.International Journal of Food Science and Technology.44: 1214-1222.

Joint Food and Agriculture Organization/ World Health Expert Committee on Food Additives, ( JECFA) 2005. Steviol glycosides. In 63rd Meeting of the Joint FAO/WHO Expert Committee on Food Additives.WHOTechnical Report Series 928.World Health Organization: Geneva. :34-39 and 138.

Khattab, S. N. M. I. Massoud, A. Abd El-Razek and M. Ayman El-Faham.2017. Physico-chemical and sensory characteristics of steviolbioside synthesis from stevioside and its application in some fruit drinks and foods. J Food Sci. Technol , 54:185-195

Marcinek K, and Z.Krejpcio .2016. Stevia rebaudianaBertoni: health promoting properties and therapeutic applications. Journal fürVerbraucherschutz und Lebensmittelsicherheit. 11:3-8.

Massoud, M. I., N. N. Zeyada, and M. Abdel Gafar .2005 . Studies on the development of low Calorie Dairy Food Products Using Fruline and Stevia Sweetener. Alex. J. of Agric. Res. 50: 47-56.

Mittal Shikha and BajwaUsha .2012.Effect of fat and sugar substitution on the quality characteristics of low calorie milk drinks. J Food Sci.Technol . 49:704-712.

Modzelewska-Kapituła M. and L.Kłębukowska .2009. Investigation of the potential for using inulin HPX as a fat replacer in yoghurt production. Int $\mathbf{J}$ Dairy Technol. 62: 209-214

Moussa, M. M., M. M. Zeitoun, M. A. Zeiton, and M. I. Massoud .2003.Physicochemical properties of stevia sweeteners as natural low coloric sweetener.. Alex. J. of Agric. Res. $48: 61-75$

Niness K .1999a. Breakfast foods and the health benefits of inulin and oligofructose. Cereal Food World 44:79-81

Rad A. H., Z. Delshadian, S. R. Arefhosseini, A.Beitollah and A. J. Mohammad .2012. Effect of Inulin and Stevia on Some Physical Properties of Chocolate Milk. Health Promotion Perspectives. 2: 42-47.

Salem, A. S. and A. R. Mowafy. 2001. Production of ice cream fortified withantioxidants (lycopene and beta carotene) as a functional food. Ann. Agri.Sci. 39: 22352242.

Salem, A. S., A. M. Abdel-Salam, and S. Elshibily.2003. Preparation and properties of low fat and sugar functional ice cream varieties. Egypt J. Dairy Sci. 31: 399-409.

Salem, S. A., and M. I.Massoud.2003. Effect of using stevia (stevia rebaudiana Bertoni) leaves powder as natural noncaloric sweetener on the physico-chemical properties of fiber fortified frozen yoghurt. Egyptian J. of Dairy Sci. 6: 61-70.

Savita S.M, K. Sheela, S. Sunanda, A.G.Shankar and P.Ramakrishna. 2010. Stevia rebaudiana - A functional component for food industry. Journal of Human Ecology. 15:261-264.

Silva R.F. 1996. Use of inulin as a natural texture modifier. Cereal Food World 41:792-794.

Singh A., K.Singh, P.Singh and M.P. Singh. 2015. Medicinal prospective and floral biology of candy leaf (Stevia rebaudianaBertoni ). International Journal of Advanced Research. 3:628-636.

Tarrega, A., and E. Costell.2006. Effect of inulin addition on rheological and sensory properties of fat free starch based dairy dessert.International Dairy Journal, 16: 1104-1112. 
Tungland B.C. and D.Meyer. 2002. Nondigestible oligo and polysaccharides (dietary fibre): their physiology and role in human health and food. Compr Rev Food Sci Food Saf. 1:73-92.
Villegas, B., and E.Costell. 2007. Flow behaviour of inulinmilk beverages. Influenceof inulin average chain length and of milk fat content.International Dairy Journal, 17 : 776-781

\section{الملخص العربي}

\section{تاعيم لبن الثيكولاته المحلى بالإستيفيوسيد منخفض السعرات الحرارية بالإنيولين كمكون وظيفى}

$$
\text { جيهان إبر اهيم صابر ، هيام حمدى محمد، زينب إسماعيل، منى إبر اهيم مسعود }
$$

أى فرق معنوي في الخواص الحسية للمنتجات المحلاة

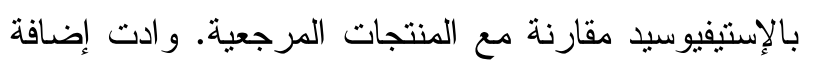

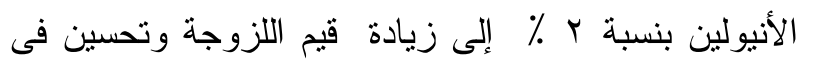

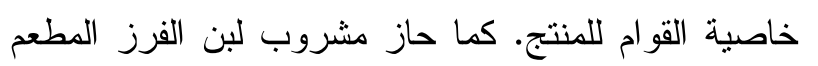

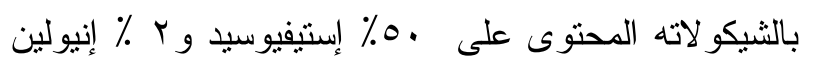

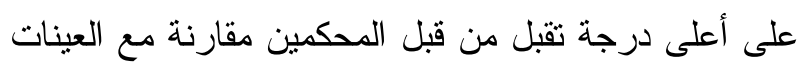

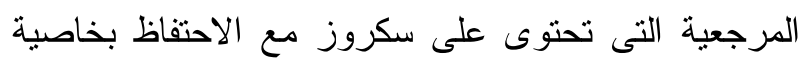

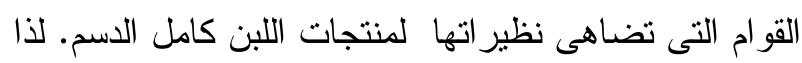

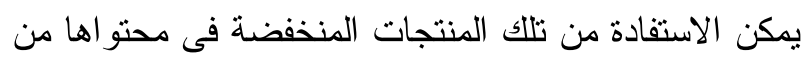
السعرات الحرارية لتلائم احتياجات الأشخاص الذين يعانون

$$
\text { من السمنة و أمر اض السكر. }
$$

الكلمات الدالة: الإستيفيوسيد ، الأنيولين ، الخواص

$$
\text { الحسية ، مرضى السكر. }
$$

أجريت هذه الدراسة لتقييم تأثير استخدام محلى

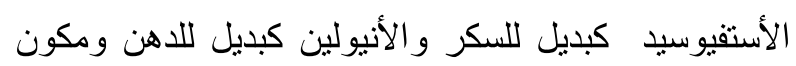
وظيفي على الفيزيوكيماوية

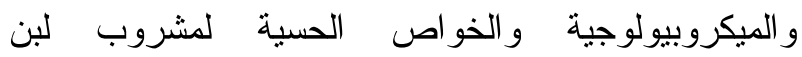

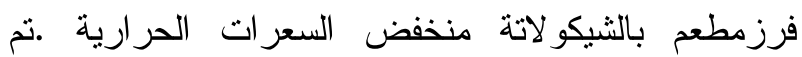

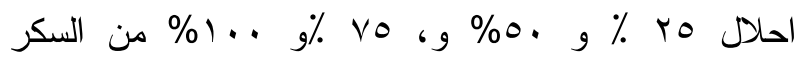
بمحلى الإستيفيوسيد لانتاج اللبن المطعم بالثيكو لاته منخفض السعرات الحرارية واضافة الإنيولين لتحسين قوام

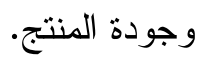

وقد أوضحت النتائج انخفاض نسبة المو اد الصلبة الذائبة

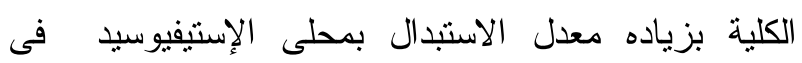

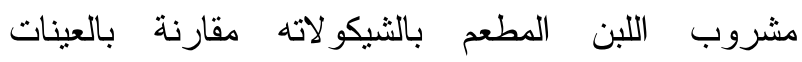
المرجعية. كما أوضحت نتائج الخو اص الحسية عدم وجود 